\title{
Short and long phases of progesterone secretion during the oestrous cycle of the African elephant (Loxodonta africana)*
}

\author{
J. D. Brannian, F. Griffin $\dagger$, H. Papkoff $\ddagger$ and P. F. Terranova \\ Department of Physiology, Ralph L. Smith Research Center, University of Kansas Medical Center, \\ Kansas City, Kansas 66103, U.S.A.; †Kansas City Zoological Park, Swope Park, Kansas City, \\ Missouri 64132, U.S.A.; and $\ddagger$ Hormone Research Institute, University of California, San Francisco, \\ California 94143, U.S.A.
}

\begin{abstract}
Summary. Serum samples were collected from 3 mature female African elephants once each week for 15-18 months. Circulating concentrations of progesterone, oestradiol and LH were determined by radioimmunoassay (RIA). The LH RIA was validated by demonstrating parallel cross-reaction with partly purified elephant LH pituitary fractions. Changing serum progesterone concentrations indicated an oestrous cycle length of $13.3 \pm 1 \cdot 3$ weeks $(n=11)$. The presumed luteal phase, characterized by elevated serum progesterone values, was $9 \cdot 1 \pm 1 \cdot 1$ weeks $(n=11)$. Two abbreviated phases of progesterone in serum lasting 2-3 weeks were observed in 2 elephants, indicating short luteal phases. Oestradiol concentrations in serum were variable, with no clear pattern of secretion. More frequent blood samples were collected during periovulatory periods and 9 distinct $\mathrm{LH}$ peaks were detected; all were followed by rises in serum progesterone concentrations. Periovulatory changes in progesterone and LH in sera correlated with external signs of oestrus and mating behaviour.
\end{abstract}

Keywords: elephant; Loxodonta; oestrous cycle; progesterone; $\mathrm{LH}$

\section{Introduction}

The oestrous cycle of the African elephant is not well characterized. Conflicting data have been reported for the length of the reproductive cycle in Asian and African elephants and the hormonal characteristics of the elephant oestrous cycle are unclear. Circulating concentrations of gonadal steroids are unusually low in female elephants compared with those in other mammalian species (Hanks \& Short, 1972; Plotka et al., 1975; Hodges et al., 1983; McNeilly et al., 1983; Hess et al., $1983)$ and this has been problematical in resolving the steroid profiles in the cycle.

A thorough study by Hess $e t$ al. (1983) has demonstrated an oestrous cycle length of about 16 weeks in the Asian elephant based on changes in serum concentrations of progesterone. This is in marked contrast to previous reports of 3-4-week oestrous cycles based on behavioural observations (Jainudeen et al., 1971; Eisenberg et al., 1971), vaginal cytology (Watson \& D'Souza, 1975), changes of oestrogen concentrations in blood (Chappel \& Schmidt, 1979) and in urine (Ramsay $e t$ al., 1981). These discrepancies in cycle length, as proposed by Hess et al. (1983), may have been due to: (1) small number of samples; (2) the use of immature bulls for Flehmen testing; and (3) the use of circulating oestrogen concentrations which may not be reliable indicators of the oestrous cycle in elephants.

\footnotetext{
*Reprint requests to: Dr Paul F. Terranova.
} 
Concentrations of gonadotrophins in the blood of the elephant have been measured (Chappel \& Schmidt, 1979; McNeilly et al., 1983; Hess et al., 1983) but convincing correlations among concentrations of luteinizing hormone (LH), follicle-stimulating hormone (FSH), follicular development and ovulation during the oestrous cycle are not evident. The purpose of our study was to elucidate changes in progesterone, oestradiol and LH in serum during the oestrous cycle of the African elephant and to correlate alterations in hormones to luteal and follicular events that normally occur in long-cycle species such as the sheep, cow and human.

\section{Materials and Methods}

Animals. The 3 elephants used in the study were nulliparous: Elephants P, 25 years old, and T, 15 years old, were housed at the Kansas City Zoological Park, Kansas City, Missouri, U.S.A., and Elephant C, 15 years old, resided at the Sedgwick County Zoo, Wichita, Kansas, U.S.A. Two immature ( 8 years old) females were kept with Elephants $P$ and T. A 35-year-old bull was kept in separate quarters in the same buildings. Elephants $P$ and T were given access to the bull for mating when they were thought to be in oestrus as determined by changes in circulating concentrations of progesterone.

Mating between the bull and Elephant $P$ was observed several times during the predicted phases of oestrus, but no pregnancies have resulted. Elephant T, on loan from Wildlife Safari Park, Winston, Oregon, U.S.A., has been housed at the Kansas City Zoo for about 2 years; no mating with the bull was observed. Elephant $C$ was kept with another female elephant of the same age and she had no contact with a male elephant at any time during the study.

The elephants were allowed to roam large outdoor enclosures during daytime hours. At night and during inclement weather the elephants were kept indoors and restrained standing with leg chains. The buildings in which the elephants were housed allowed for a natural exposure to light. Supplemental lighting was provided between 08:00 and 17:00 $\mathrm{h}$ when the animals, at times, had to be kept indoors. The elephants were fed a standard zoo ration of fortified grain and hay.

Blood collection. Blood $(5-10 \mathrm{ml})$ was collected from ear or leg veins of unanaesthetized elephants. Blood was allowed to clot overnight at $4^{\circ} \mathrm{C}$. Serum was collected and stored frozen at $-20^{\circ} \mathrm{C}$ until subjected to radioimmunoassay. Samples were taken at weekly intervals for $\simeq 18$ months (April 1986-September 1987). Based on fluctuating serum concentrations of progesterone, luteal and follicular phases were evident. To determine when LH peaks in serum occurred, more frequent blood samples $(22-24 \mathrm{~h}$ intervals) were taken during the presumed late follicular phases.

Radioimmunoassays. Progesterone and oestradiol- $17 \beta$ were measured after extraction of serum with 2 volumes anhydrous diethyl ether which yields $85-90 \%$ recovery of steroids. Anti-progesterone-11-BSA (GDN 337 from Dr G. Niswender, Colorado State University, Fort Collins, CO, U.S.A.) and anti-oestradiol-6-thyroglobulin $\left(\mathrm{E}_{2}-\mathrm{TG}-\mathrm{K}\right.$ from Dr D. Collins, Emory University, Decatur, GA, U.S.A.) were used for RIA. The methodology and cross-reactivities have been reported (Terranova, 1981). Parallelism was demonstrated using different amounts of serum; for progesterone, $0 \cdot 1-0.3 \mathrm{ml}$ were used and for oestradiol, $1.0-1.5 \mathrm{ml}$. Levels of sensitivity for the steroid assays were approximately $4 \mathrm{pg}$ oestradiol $/ \mathrm{ml}(1 \mathrm{ml}$ samples) and $20 \mathrm{pg}$ progesterone $/ \mathrm{ml}(0.2 \mathrm{mi}$ samples). Steroid concentrations below the limit of assay sensitivity were recorded as equal to the lower limit; i.e. oestradiol, $4 \mathrm{pg} / \mathrm{ml}(\simeq 15 \%$ of samples) and progesterone, $20 \mathrm{pg} / \mathrm{ml}$ ( $<5 \%$ of samples). Intra- and inter-assay coefficients of variation at $50 \%$ binding were $8.7 \%$ and $6 \cdot 3 \%$, respectively, for progesterone and $11.9 \%$ and $9 \cdot 9 \%$, respectively, for oestradiol. These calculations were based on duplicate determinations of 9 assays for progesterone and 5 assays for oestradiol.

The LH radioimmunoassay utilized rabbit anti-ovine LH (GDN No. 15) and ${ }^{125}$ I-labelled ovine LH (NIADDKoLH-I-3) as described by Niswender et al. (1968) against NIADDK rat-LH RP-2 standard preparation. Sensitivity for the LH assay was $0.5 \mathrm{ng} / \mathrm{ml}(0.2 \mathrm{ml}$ samples). Intra- and inter-assay coefficients of variation were $6.3 \%$ and $12.9 \%$, respectively, for duplicates of 5 assays. This assay was validated for measurement of elephant LH by demonstrating cross-reactivity with purified elephant pituitary LH (see below).

Extraction of elephant pituitaries. The methods used for partial purification of elephant LH and FSH have been previously described in detail (Matteri et al., 1987a). In brief, tissue from 3 frozen elephant pituitaries $(2.5 \mathrm{~g}$ frozen weight tissue obtained by Dr B. L. Lasley and Dr K. Benirschke) was homogenized and extracted at $\mathrm{pH} 9 \cdot 5$. A portion (about $1 \%$ ) of the initial extract was dialysed and lyophilized (designated PK-IE). The remainder of the extract was adjusted to $\mathrm{pH} 4.5$ with metaphosphoric acid, resulting in the precipitation of a fraction containing the growth hormone and prolactin. This precipitate was dissolved, dialysed and lyophilized, yielding $106 \mathrm{mg}$ (PK-IMP). The glycoproteins contained in the supernatant fluid were precipitated with $\mathrm{NH}_{4} \mathrm{I}_{2} \mathrm{SO}_{4}(0.8$ saturation, $\mathrm{pH} 7 \cdot 0)$, dissolved, dialysed and lyophilized, yielding $44 \mathrm{mg}$ (PK-IMS). Most of the glycoprotein fraction $(42 \mathrm{mg}$ ) was then subjected to chromatography on a column of sulphopropyl-Sephadex C50. The unadsorbed (FSH) fraction (PK-2A) amounted to $35 \mathrm{mg}$. The absorbed fraction (PK-2B), containing LH and possibly TSH, yielded $3 \cdot 3 \mathrm{mg}$. 
Validation of LH assay. Tests of parallelism were performed between the rLH-PR-2 standard preparation and various elephant pituitary extracts. ${ }^{125} \mathrm{I}$-labelled oLH and antiserum to oLH were incubated with $0 \cdot 1,0 \cdot 5,1 \cdot 0,10,100$ and $500 \mathrm{ng} / \mathrm{RP}-2$ (rat standard), e98a (equine LH standard) and elephant pituitary extracts PK-IE, PK-IMS, PKIMP, PK-2A and PK-2B. Curves parallel to RP-2 and e98A standard curves were obtained for elephant pituitary extracts PK-2B, PK-IMS, PK-IE and PK-2A (Fig. 1). Percentage cross-reactivity with RP-2 (at 50\% binding) for each of these fractions was as follows: PK-2B $(\mathrm{LH})=14.4 \%$; PK-IMS (glycoproteins) $=2 \cdot 6 \%$; PK-IE (initial extract $)=2.5 \%$; and PK-2A (FSH) $=0.6 \%$.

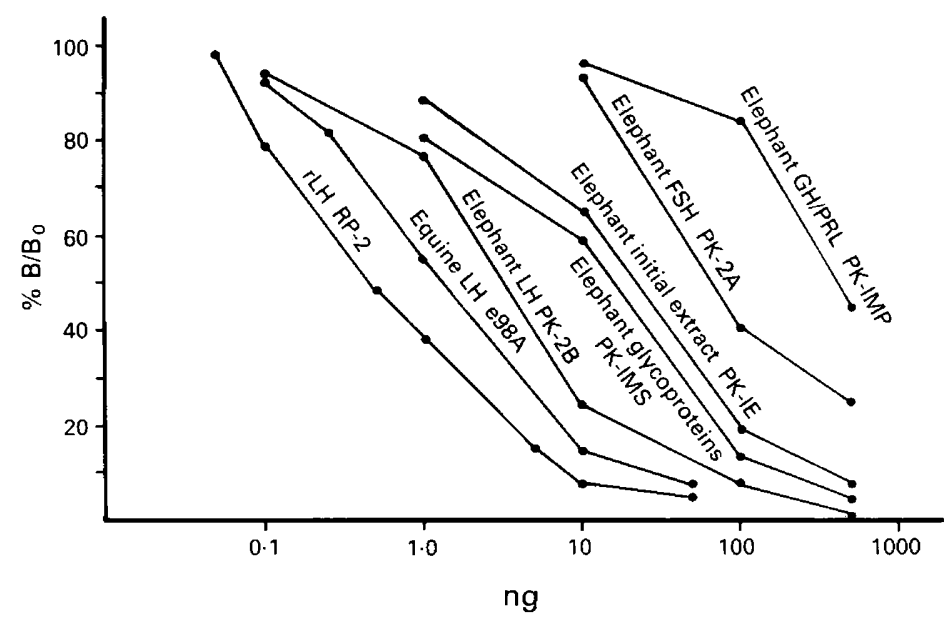

Fig. 1. Radioimmunoassay displacement (dose-response) curves of elephant pituitary fractions compared with rLH-RP-2. The radiolabelled ligand was ${ }^{125}$ I-labelled oLH and anti-oLH was used.

Behavioural observations. An attempt was made to correlate periovulatory hormonal changes with mating behaviour, urine testing by the bull and any other external signs at oestrus. Urine testing by the bull was recorded from random observations by keepers when the bull was allowed access to the females.

Statistics. Data from hormone assays were analysed by 1-way analysis of variance with a modification for repeated measures. When significant differences were detected $(P \leqslant 0.05)$ by 1 -way analysis of variance, then Duncan's Multiple Range Test was used to determine the location of the significant difference.

\section{Results}

\section{Progesterone, oestradiol and $L H$ concentrations}

Serum progesterone concentrations measured at 1-week intervals are shown in Fig. 2 . The luteal phase was defined by progesterone values $>40 \mathrm{pg} / \mathrm{ml}$, based on basal values of $40 \mathrm{pg} / \mathrm{ml}$ or less throughout the oestrous cycle. The lowest values detectable were $\simeq 20 \mathrm{pg} / \mathrm{ml}$. Luteal-phase progesterone concentrations reached a maximum of $278 \mathrm{pg} / \mathrm{ml}$ but usually did not exceed $200 \mathrm{pg} / \mathrm{ml}$. The average duration of the luteal phases in these elephants was 9 weeks $(9 \cdot 1 \pm 1 \cdot 1$ weeks, $n=11)$, excluding 2 periods of abbreviated progesterone secretion (to be discussed later). The follicular phase was defined by serum progesterone values of $<40 \mathrm{pg} / \mathrm{ml}$ and this portion of the cycle lasted $4 \cdot 1 \pm 0 \cdot 6$ weeks $(n=11)$. The length of one complete oestrous cycle therefore averaged $13 \cdot 3 \pm 1 \cdot 3$ weeks $(n=11)$.

Oestradiol concentrations in serum are also shown in Fig. 2. Values ranged from $<4$ to $52 \mathrm{pg} /$ ml. No clear pattern of oestradiol secretion was apparent. Oestradiol values exceeded $20 \mathrm{pg} / \mathrm{ml}$ during only one cycle (Fig. 2a). 

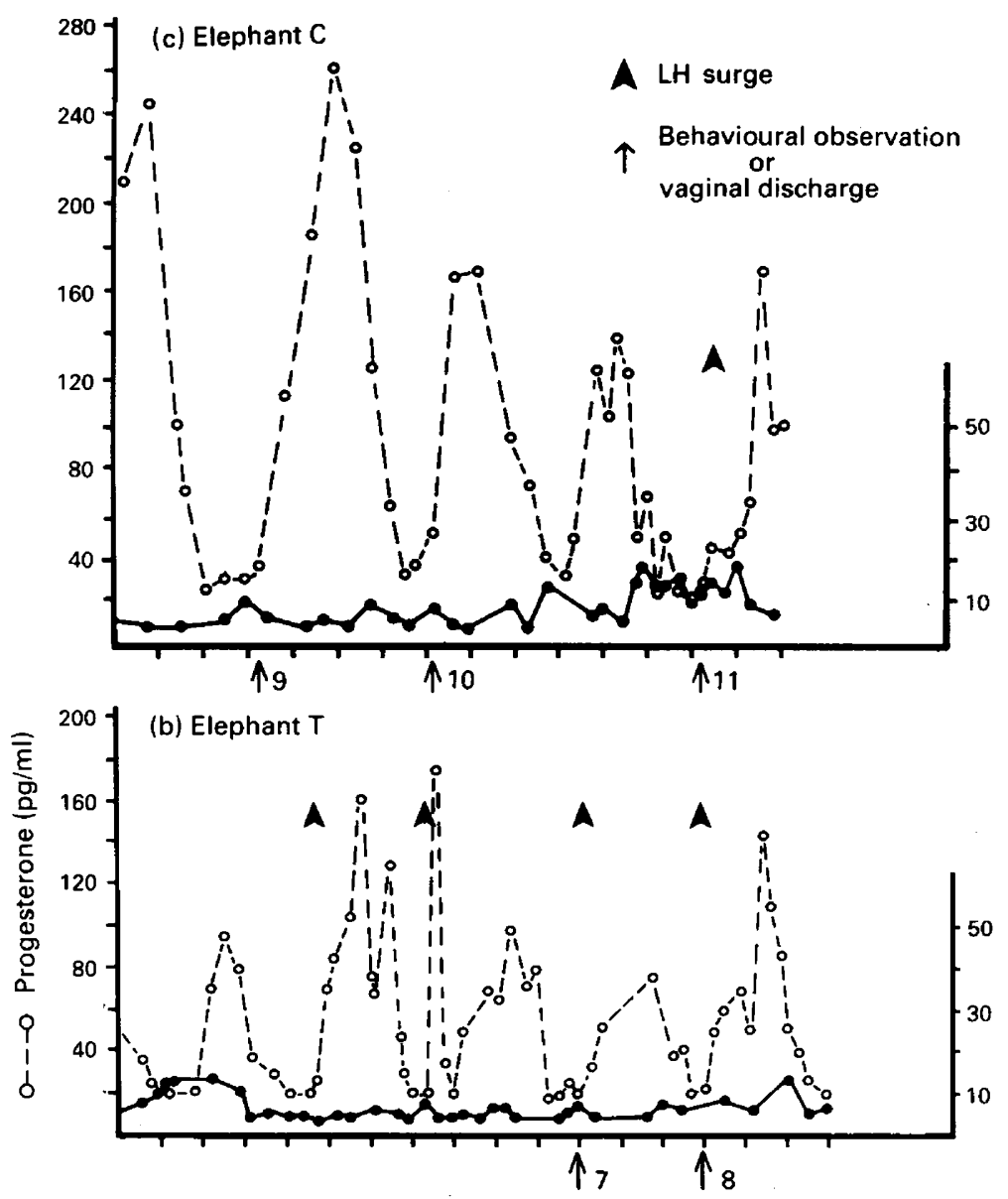

(a) Elephant P

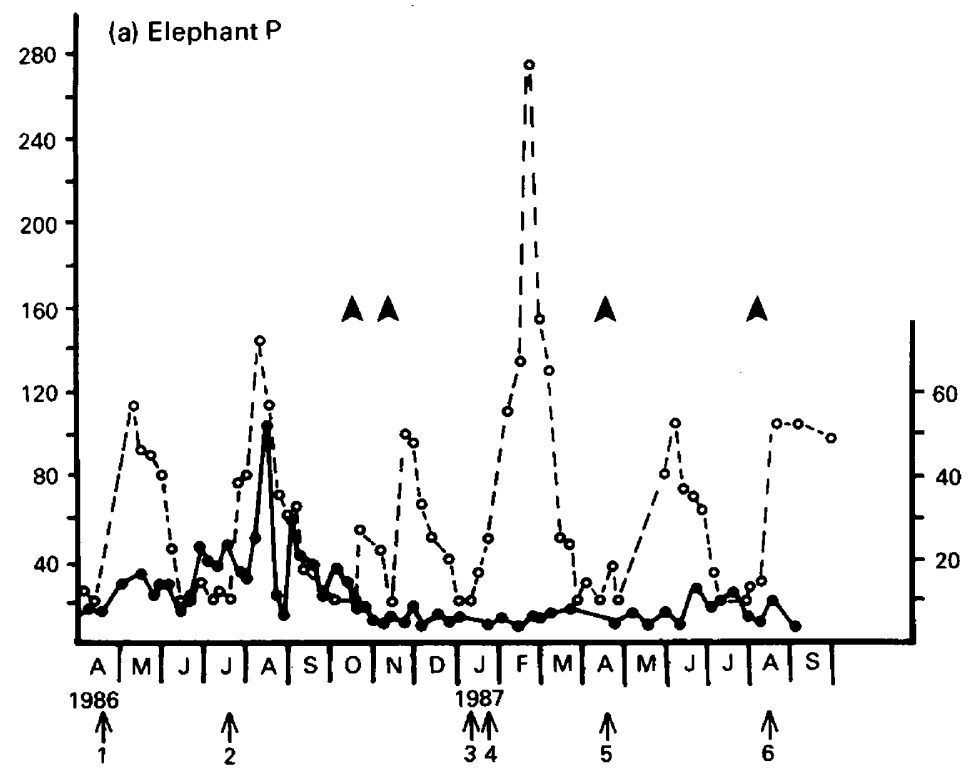


To determine the time course of LH surges during the preovulatory period, daily blood samples were taken during some of the transition periods from follicular to luteal phases. LH immunoreactivity remained near the lower limit of assay sensitivity (i.e. $0.5 \mathrm{ng} / \mathrm{ml}$ ) throughout each period, excluding a single surge of LH in each sampling period (Fig. 3). This sampling regimen resulted in detection of 5 distinct LH surges (Fig. 3), at least one in each elephant. Due to concern about the stressfulness of daily bleeding, during subsequent periovulatory periods, samples were collected at 72-h intervals from Elephants $P$ and $T$. Two additional LH peaks were observed during these periods (Fig. 3). It appears from these results that peaks of $\mathrm{LH}$ were detectable for 24-48-h periods and that the LH peaks were closely followed by significant increases in serum progesterone concentrations (Fig. 3) above $40 \mathrm{pg} / \mathrm{ml}$. Values $>40 \mathrm{pg} / \mathrm{ml}$ were considered as the beginning of significant rises because thereafter values always increased to at least 1.5 times that value $(40 \mathrm{pg} / \mathrm{ml})$. Rises in serum progesterone concentrations usually occurred 1-2 days after the LH peak (Fig. 3a, c, d, e, g) as measured in daily samples and always within 1 week (Fig. 3b, f) after the LH surge. In addition, elevations in serum LH were observed in one weekly sample taken from Elephant $P$ on 14 November 1986, and from Elephant T on 28 August 1986 (Fig. 2a, b); both animals were in expected oestrus. LH remained at basal levels in all other samples taken weekly from each elephant (data not shown).

Serum progesterone concentrations during the luteal phase of 2 cycles (Elephant $\mathbf{P}$, OctoberNovember 1986, and Elephant T, November-December 1986) revealed an unexpected pattern. Progesterone values remained increased $(>40 \mathrm{pg} / \mathrm{ml})$ for about $2-3$ weeks then declined to $<20 \mathrm{pg} / \mathrm{ml}$ (Fig. 2a, b). The week after this decline, progesterone concentrations again increased and remained elevated for at least the next 5 weeks. During this period of low serum progesterone, Elephant P exhibited a surge of LH (Fig. 2a). Therefore, Elephant P experienced two LH peaks approximately 3 weeks apart. Since only weekly samples were being collected during these periods of premature progesterone decline, it is not known whether Elephant $\mathrm{T}$ also experienced a second LH surge.

\section{Behavioural observations}

Although behavioural signs of oestrus in female African elephants have been documented in wild populations (Moss, 1983), these signs are difficult to discern in a captive situation. Most of these signals relate to subtle social interactions with other females or with males. In the context of captivity, interpretations of such behaviour becomes very subjective. A very discrete Flehmen-like response has been described for Asian elephants in captivity (Rasmussen et al., 1982). African bull elephants have been observed to exhibit a similar urine-testing response (Moss, 1983), but this has not been adequately described for captive elephants. Elephants $P$ and $T$ at the Kansas City Zoo were exposed to a mature bull during times of suspected oestrus. Urine testing by the bull was observed on two occasions, both times before mounting and intromission (Table 1). On some occasions, Elephants $\mathrm{P}$ and $\mathrm{T}$ were housed in a large enclosure with the bull for several hours to several days during periods of suspected oestrus. The lack of an observed urine test should not therefore be taken as evidence that one did not occur or that the females were not in oestrus. The only indisputable indication of oestrus in captivity appears to be receptivity to mounting by a mature bull. During this study, mounting and intromission were observed on 3 occasions (Table 1). In each case, the same female, Elephant $\mathbf{P}$, was involved. All 3 matings were closely associated with increases in serum progesterone from follicular to luteal phase levels (Fig. 2a). LH peaks in serum

Fig. 2. Serum progesterone and oestradiol concentrations during an 18-month period in Elephants P (a), T (b) and C (c). $\mathbf{\Delta}$ indicate LH peaks, $\uparrow$ indicate external indications of oestrus (see Table I for description). 


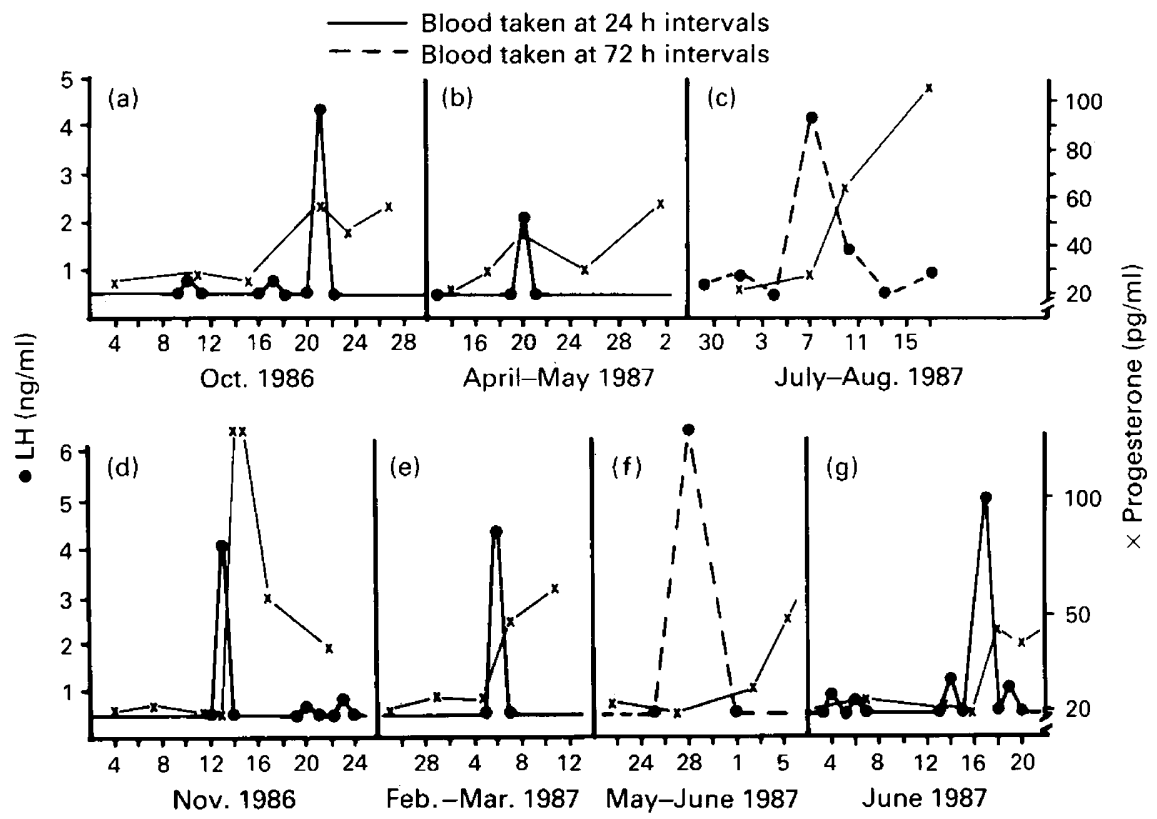

Fig. 3. Serum LH concentrations during 7 periovulatory periods from Elephants $P, T$ and $C$ based on daily blood sampling $(a, b, d, e, g)$ or 72-h sampling intervals (c, f). Temporal relationships with increases in serum progesterone are shown.

were also detected within 1-2 days before or after mating on 2 of these occasions (Fig. 2a). Daily blood samples were not being collected at the time of the other observed mating. When compared with cycles in which mating did not occur, mating did not alter the length of the subsequent luteal phase or the length of the next follicular phase.

In addition, elephant keepers at both the Kansas City and Sedgwick County Zoos noted periodic discharges of an amorphous, mucus-like secretion from the vulvar area of all 3 female elephants under study. These discharges showed a close temporal relationship with increases in serum progesterone concentration and during 5 periovulatory periods occurred within 2 days of an $\mathbf{L H}$ peak (Table 1; Fig. 2). The occurrence of these discharges was therefore taken as supplementary confirmation of oestrus.

Table 1. Behavioural oestrous events and occurrence of vaginal secretions in Elephants $\mathrm{P}, \mathrm{T}$ and $\mathrm{C}$

\begin{tabular}{llcl}
\hline Event* & \multicolumn{1}{c}{ Date } & Elephant & Behaviour \\
\hline 1 & 17 April 1986 & $\mathbf{P}$ & Mounting and intromission by bull \\
2 & 18 July 1986 & $\mathbf{P}$ & Vaginal secretion \\
3 & 10 January 1987 & $\mathbf{P}$ & Vaginal secretion \\
4 & 20 January 1987 & $\mathrm{P}$ & Vaginal secretion \\
5 & 19-20 April 1987 & $\mathrm{P}$ & Vaginal secretion; urine test; mounting and intromission by bull \\
6 & 9-10 August 1987 & $\mathrm{P}$ & Vaginal secretion; urine test; mounting and intromission by bull \\
7 & 6 March 1987 & $\mathrm{T}$ & Vaginal secretion \\
8 & 27 May 1987 & $\mathrm{T}$ & Vaginal secretion \\
9 & 13 August 1986 & $\mathrm{C}$ & Vaginal secretion \\
10 & 27 November 1986 & $\mathrm{C}$ & Vaginal secretion \\
11 & 10 June 1987 & $\mathrm{C}$ & Vaginal secretion \\
\hline
\end{tabular}

\footnotetext{
*Numbers correspond to numbered arrows in Fig. 2.
} 


\section{Discussion}

Based on changes in serum concentrations of progesterone it is calculated that the African elephant exhibits a 13-14-week oestrous cycle. The cycle length is similar to that in the Asian elephant as proposed by Hess et al. (1983) who observed a 16-week cycle. Our results differ from previous reports proposing a 3-week oestrous cycle in the elephant (Jainudeen et al., 1971; Eisenberg et al., 1971; Watson \& D'Souza, 1975; Chappel \& Schmidt, 1979; Ramsay et al., 1981). Nevertheless, our data may provide insight into the reasons for the reporting of short oestrous cycles ( 3 weeks). Firstly, it appears that serum concentrations of progesterone provide a distinct profile of the oestrous cycle in the African elephant. Serum concentrations of progesterone were typically increased during what is assumed to be the luteal phase of the cycle. Progesterone values in serum increased shortly after (1-2 days) peaks of LH were detected in serum. The increase in serum progesterone correlated with the onset of the luteal phase (based on hormonal profiles in other long cycle species, i.e. cow, sheep, human). Thereafter, progesterone values in the serum remained increased for 2-3 weeks $(n=2)$ or $8-9$ weeks $(n=11)$ (Fig. 2$)$ which may provide an hormonal basis for short and long cycles, respectively. Two elephants exhibited at least 1 short phase of progesterone secretion and each elephant exhibited at least 2 consecutive long phases of progesterone secretion (Fig. 2). Secondly, our measurements of serum concentrations of LH showed one animal with two LH surges 3 weeks apart. A 3-week oestrous cycle may indeed be possible but a 13-14-week cycle seems more usual based primarily on serum concentrations of progesterone. The 3-week cycle may represent a short luteal phase in which circulating progesterone concentrations decline prematurely as has been shown in primates (diZerega \& Hodgen, 1981). In primates, the early decline in circulating progesterone is a characteristic of luteal insufficiency and is due to a lack of FSH stimulation during the follicular phase (diZerega \& Hodgen, 1981).

Serum and plasma concentrations of gonadotrophins have been measured in wild African elephants by McNeilly et al. (1983), but since these were single samples no correlation with cyclic events was made. Chappel \& Schmidt (1979) and Hess et al. (1983) measured LH immunoreactivity in cyclic Asian elephants. Both were able to show periodic increases in serum LH values but neither demonstrated a definite correlation between these peaks of LH activity and progesterone and the suspected occurrence of ovulation. Chappel \& Schmidt (1979) reported two prolonged (5-6 days) rises in serum LH during a 40-day period which correlated with increases in oestradiol values. This pattern of LH is in contrast to our LH data. LH peaks in Asian elephants observed by Hess et al. (1983) could not be consistently correlated with increases in progesterone concentrations. The reasons for these differences are unknown but may be related to differences in gonadotrophin radioimmunoassays and species.

Our results indicate that the LH surge lasts only 1-2 days in contrast to earlier results (Chappel \& Schmidt, 1979). However, considering the sensitivity of the assay and the presence of smaller peaks of LH activity associated with the maximum peak as seen in Fig. 3(g), it is possible that $\mathrm{LH}$ may increase more gradually over several days, but our assay only detects the larger peaks. So far we have detected 9 LH surges, all of which were followed by significant increases in plasma progesterone (Fig. 2). The rapid (over a 24 -h period) rise in progesterone from follicular to luteal phase levels has also been observed in the Asian elephant (Hess et al., 1983). That progesterone can rise so quickly after the LH surge is somewhat unusual for a large mammal. However, a similar pattern is seen in the horse in which progesterone concentrations increase concurrently or within $24 \mathrm{~h}$ after the LH peak (Nett et al., 1976). Comparison with the horse is particularly intriguing considering the frequent presence of persistent luteal tissue in the horse (Stabenfeldt et al., 1975) and in African and Asian elephants (Hanks \& Short, 1972; Smith \& Buss, 1975). Further characterization of the normal pattern of LH secretion in the African elephant may provide additional insight into the causes of abbreviated progesterone production. That ovulation occurs at the time of the LH surge(s) has not been confirmed; possibly the second LH surge occurring 3 weeks after the preceding surge of LH either induces ovulation or rejuvenates a premature regressing corpus luteum. 
The RIA for LH used in these studies was validated by studying elephant pituitary LH and demonstrating parallelism with the rat $\mathrm{LH}$ used as standard. The most purified elephant LH fraction, PK-2B, was also tested in another RIA which uses a monoclonal antibody against bovine LH (Matteri et al., 1987b). This RIA is responsive to virtually every mammalian species of LH and showed PK-2B to be 0.2 as active as NIH-LH-S18. A similar degree of activity was seen in a radioreceptor assay which used rat testis membranes and horse $\mathrm{LH}$ as radioligand.

Serum oestradiol concentrations did not reflect a discernible pattern and could not be correlated with cyclic events. Since oestradiol concentrations were generally near or below the lower limit of assay sensitivity, characterization of oestradiol secretion in this species awaits development of more sensitive assay techniques.

Preliminary examination of the amorphous mucus-like secretions from the vulvar area of the 3 elephants indicates that when dried it produces a ferning pattern as observed in dried human vaginal secretions (Rydberg, 1949).

We thank the staff of the Kansas City Zoo, Ralph Waterhouse (Director), Ernest Hagler (past Director), Mike Blakely (Curator of Mammals), Roger Brannian (D.V.M.); the animal health staff; and the elephant management staff (David Collins, Sally Latorres, Eric Easton, Karrie Wiley, Jim Black and Bob Thornton); the staff of the Sedgwick County Zoo, R. L. Blakely (Director), Ken Redman (General Curator), William Bryant (D.V.M.) and Scott Carter (Senior Keeper). This work was supported by a grant from the Nixon Griffis Fund for Zoological Research, New York Zoological Society (P.F.T.) and by a grant from the NSF (DCB 87-10021 to H.P.).

\section{References}

Chappel, S.C. \& Schmidt, M. (1979) Cyclic release of luteinizing hormone and the effects of luteinizing hormone-releasing hormone injection in Asiatic elephants. Am. J. vet. Res. 40, 451-453.

diZerega, G.S. \& Hodgen, G.D. (1981) Folliculogenesis in the primate ovarian cycle. Endocrine Reviews 2, $27-49$.

Eisenberg, J.F., McKay, G.M. \& Jainudeen, M.R. (1971) Reproductive behavior of the Asiatic elephant (Elephas maximus). Behaviour 38, 193-224.

Hanks, J. \& Short, R.V. (1972) The formation and function of the corpus luteum in the African elephant, Loxodonta africana. J. Reprod. Fert. 29, 79-89.

Hess, D.L., Schmidt, A.M. \& Schmidt, M.J. (1983) Reproductive cycle of the Asian elephant (Elephas maximus) in captivity. Biol. Reprod. 28, 767-773.

Hodges, J.K., Henderson, C. \& McNeilly, A.S. (1983) Circulating estrogen concentrations during pregnancy in the African elephant (Loxodonta africana). J. Reprod. Fert. 67, 121-127.

Jainudeen, M.R., Eisenberg, J.F. \& Tilakeratne, N. (1971) Oestrous cycle of the Asiatic elephant, Elephas maximus, in captivity. J. Reprod. Fert. 27, 321-328.

Matteri, R.L., Baldwin, D.M., Lasley, B.L. \& Papkoff, H. (1987a) Biological and immunological properties of zebra pituitary gonadotropins: comparison with horse and donkey gonadotropins. Biol. Reprod. 36, 1134-1141.

Matteri, R.L., Roser, J.F., Baldwin, D.M., Lipovetsky, V. \& Papkoff, H. (1987b) Characterization of a monoclonal antibody which detects luteinizing hormone from diverse mammalian species. Dom. Anim. Endocr. 4, 157-165.
McNeilly, A.S., Martin, R.D., Hodges, J.K. \& Smuts, G.L. (1983) Blood concentrations of gonadotrophins, prolactin and gonadal steroids in males and in nonpregnant and pregnant female African elephants (Loxodonta africana). J. Reprod. Fert. 67, 113-120.

Moss, C. (1983) Oestrous behaviour and female choice in the African elephant. Behaviour 86, 167-196.

Nett, T.M., Pickett, B.W., Seidel, G.E. \& Voss, J.L. (1976) Levels of luteinizing hormone and progesterone during the estrous cycle and early pregnancy in mares. Biol. Reprod. 14, 412-415.

Niswender, G.D., Midgeley, A.R., Monroe, S.E. \& Reichert, L.E. (1968) Radioimmunoassay for rat LH with anti-ovine LH serum and ovine LH-I ${ }^{131}$. Proc. Soc. exp. Biol. Med. 128, 807-811.

Plotka, E.D., Seal, U.S., Schobert, E.E. \& Schmoller, G.C. (1975) Serum progesterone and estrogens in elephants. Endocrinology 97, 485-487.

Ramsay, E.C., Lasley, B.L. \& Stabenfeldt, G.H. (1981) Monitoring the estrous cycle of the Asian elephant (Elephas maximus), using urinary estrogens. Am. J. vet. Res. 42, 256-260.

Rasmussen, L.E., Schmidt, M.J., Henneous, R., Groves, D. \& Daves, G.D. (1982) Asian bull elephants: Flehman-like responses to extractable components in female elephant estrous urine. Science, N.Y. 217, 159-162.

Rydberg, E. (1949) Observations on the crystallization of the cervical mucus. Acta obstet. gynaec. scand. 28, $172-187$.

Smith, N.S. \& Buss, I.O. (1975) Formation, function and persistence of the corpora lutea of the African elephant (Loxodonta africana). J. Mammal. 56, 30-43. 
Stabenfeldt, G.H., Hughes, J.P., Evans, J.W. \& Geschwind, I.I. (1975) Unique aspects of the reproductive cycle of the mare. J. Reprod. Fert., Suppl. 23, 155-160.

Terranova, P.F. (1981) Steroidogenesis in experimentally induced atretic follicles of the hamster: a shift from estradiol to progesterone synthesis. Endocrinology 108, 1885-1890.
Watson, P.F. \& D'Souza, F. (1975) Detection of oestrus in the African elephant (Loxodonta africana). Theriogenology 4, 203-209.

Received 26 February 1988 